\author{
Cadernos de \\ ESTUDOS LINGUÍSTIICOS - (58.3), Campinas, pp. 401-424 - set./dez. 2016
}

\title{
THE ANALYSIS OF LANGUAGES IN CONTACT: A CASE STUDY THROUGH A VARIATIONIST LENS
}

\author{
ANA MARIA CARVALHO ${ }^{1}$
}

\begin{abstract}
RESUMO: Este artigo descreve as contribuições da sociolinguística variacionista aos estudos de línguas em contato. Após um histórico do desenvolvimento dessa linha de pesquisa e de suas implicações teóricas e metodológicas, a expressão do pronome sujeito com referentes de terceira pessoa do singular é examinada nas variedades do português e do espanhol faladas no norte do Uruguai. Com base na sociolinguística comparativa, constata-se que a distribuição dessa variável na fala de bilingues não apresenta indicios de convergência. Finalmente, chama-se a atenção para a necessidade de mais estudos sobre dialetos de português em contato com outros idiomas dentro das premissas da sociolinguística variacionista.
\end{abstract}

Palavras-Chave: línguas em contato; expressão de pronome sujeito; português uruguaio; espanhol uruguaio.

RESUMEN: El artículo discute las contribuciones de la sociolingüística variacionista a los estudios sobre lenguas en contacto. Tras un resumen sobre el desarrollo del área y sus implicaciones metodológicas y teóricas, se examina la expresión del pronombre sujeto de tercera persona en español y portugués en contacto en el norte de Uruguay. Basados en la sociolingüística comparativa, los resultados demuestran que esa variable no muestra convergencia de sistemas entre los bilingües. Por último, se llama la atención a la necesidad de más estudios sobre dialectos del portugués en contacto con otras lenguas dentro del marco de la sociolingüística variacionista.

Palabras clave: lenguas en contacto; expresión del pronombre sujeto; portugués uruguayo; español uruguayo.

\section{INTRODUCTION}

Despite the fact that Uriel Weinreich, the author of the benchmark book Languages in Contact (1953), was William Labov's mentor, variationist linguistics was not applied to the analysis of language-contact situations until much later, a delay Labov attributed to Weinreich's premature death (GORDON 2006:334). This delay resulted in decades of what Nagy and Meyerhoff (2008:7-9) have called "the monolingual bias in quantitative perspective." Then in 1993 Poplack applied the variationist method to the analysis of bilingual varieties ${ }^{2}$, making an important contribution to the field of languages in contact by revealing the

\footnotetext{
${ }^{1}$ University of Arizona.

${ }^{2}$ However, please note prior important quantitative treatments of bilingual varieties, including, among many others, Mougeon and Beniak (1991), Poplack (1988), Rickford (1980), and Sankoff (1980).
} 
CARVALHO - The analysis of languages in contact: a case study though a variationist lens

orderly heterogeneity (WEINREICH; LABOV; HERZOG 1968) behind the variable nature of contact dialects; and, most importantly, providing a tool for the systematic examination of the relationship between language contact and linguistic change. In this article, I summarize the methodological and theoretical premises behind variationist approaches to languages in contact, illustrate these approaches by analyzing subject pronoun expression with third-person singular referents in a context where Portuguese coexists with Spanish, and emphasize the challenges of analyzing the effects of contact between cognate languages. I conclude by advocating for more research along this line to further explore the characteristics of Portuguese dialects in contact with other languages.

The rationales for using a variationist method to study varieties that coexist with other languages in a given speech community are derived from the theoretical premises presented in Labov's seminal 1966 work: (i) variation is inherent to any linguistic system, (ii) variation is not random, and (iii) variation precedes change but does not guarantee change. These are substantive contributions given that nonvariationist linguists often consider bilingual dialects to be unpredictably variable and vulnerable to contact-induced changes. Methodologically speaking, Labov also introduced a groundbreaking redefinition of what constitutes linguistic data. Instead of selected examples of overheard language production, he advocated for long-term observation of sociolinguistic norms in a speech community and for recording of speech samples that are as close as possible to the vernacular. An exhaustive, quantitative treatment of linguistic data follows, involving examination of both internal and external factors that are hypothesized to condition variation, in order to detect patterns of language use behind what might appear to be random heterogeneity.

These basic variationist premises for the study of bilingual dialects represent a radical departure from traditional studies of language-contact situations. Traditional, mostly qualitative, studies emphasized contact features based on selected examples taken out of context and used to illustrate linguistic behavior as if it were categorical. This approach exaggerated the impact of contact on dialects spoken by bilinguals (POPLACK 1993:p. 253), leading to the erroneous perception that contact-induced change is unavoidable in bilingual contexts, even though "contact-induced change is not an inevitable nor possibly even a common outcome of language contact" (POPLACK; LEVEY 2010:412). As Torres Cacoullos and Travis (2010) argued, these excessive conclusions about the effect of contact are probably attributable to the tendency among scholars of language contact to equate individual observations of nonstandard contact-induced forms with linguistic change. Quantitative treatment of data derived from a representative sample of the population permits us to "disregard imagined examples and isolated tokens, which are neither representative nor recurrent, in favor of the regular tendencies that characterize natural exchanges in the community" (POPLACK; MEECHAN 1998:129). In addition, variationist analyses also differ from experimental studies, in that while the latter may reveal important nuances of bilinguals' linguistic production and perception, they may produce results that are not representative of language production in ordinary settings, since they rely on manipulation tasks 402 
Cadernos de ESTUDOS LINGUÍSTICOS (58.3) - set./dez. 2016

that are unfamiliar to most speakers (NAGY 2015:324-325; POPLACK; LEVEY 2010:396). Whether analyzing monolingual or bilingual populations, variationists examine naturally occurring data in an attempt to capture the spontaneous oral production characteristic of linguistic practices in the speech community.

Labovian sociolinguistic interviews are a technique that yields controlled data representative of the vernacular while enabling accurate comparisons with other dialects, an essential element in assessing contact-induced linguistic changes. In fact, the assessment of linguistic changes - which entails the ability to study the gradual incorporation of a linguistic innovation into the grammar of a community - is indisputably a major contribution of variationist analysis to linguistics in general and to languages in contact in particular. In the case of bilingual dialects, variationist analysis based on a large sample of spontaneous speech allows for a careful distinction between community variation and idiosyncratic behavior. Once variation is detected, quantitative results can tentatively classify the variable as a stable variation or a change in progress. If the results indicate a change in progress, the method can distinguish between changes driven by a language's structural tendencies (internal) versus those caused by contact with another language (external). Only if external influences are detected can contactinduced changes be asserted.

In informal in-group conversations with other bilinguals, balanced bilinguals will usually relax their language barriers and produce a plethora of contact features such as lexical borrowings; calques; code-switches; and phonetic, morphological, and syntactic hybrid constructions. But as Labov (1972) demonstrated, the linguistic behavior of an individual may be ephemeral and idiosyncratic. Therefore, the question facing variationists who examine bilingual dialects is whether contact features are sufficiently widespread in both individual and community repertoires that they displace other structures in the host language and consequently become part of the community grammar that will be transmitted to the next generation. In what follows I delineate how such an analysis is carried out.

\section{VARIATIONIST METHODS IN THE STUDY OF LANGUAGES IN CONTACT}

In her seminal article "Variation theory and language contact" (1993), Poplack demonstrates how the variationist method can be successfully applied to the study of contact varieties. She explains the appropriateness of the variationist method of data collection, the manipulation of data, and a plethora of social aspects of bilingual societies that need to be considered in studies of contact varieties. Her main focus is on the analysis of contact features such as lexical borrowings and code-switching, an agenda further developed by her and her associates, especially useful in discerning code-switching from borrowings (AARON 2014, BESSETT 2017, POPLACK; SANKOFF; MILLER 1988, POPLACK; MEECHAN 1998, TORRES CACOULLOS; AARON 2003). In this article, however, I focus on Poplack's applications of variationist comparative 
CARVALHO - The analysis of languages in contact: a case study though a variationist lens

sociolinguistics to the examination of morphosyntactic variance in contact dialects (see POPLACK 1997, POPLACK; LEVEY 2010, POPLACK; ZENTZ; DION 2012), which have been replicated in studies of bilingual varieties in Europe (BLAS ARROYO 2014, ZABRODSKAJA 2013), Asia (MEYERHOFF 2009a, 2009b), South America (CARVALHO; BESSETT 2015), and North America (NAGY 2015, OTHEGUY; ZENTELLA 2012; SHIN; MONTESALCALÁ 2014; BESSETT 2015; among many others). While this analytical framework follows procedures that are similar to current standard methodology in language variation and change, some differences emerge in language-contact situations, as I briefly explore here.

Among Poplack's important claims, one worthy of emphasis is the need for appropriate data collection protocols in bilingual environments where the minority language is stigmatized. In these contexts, it is extremely important that interviews be carried out by "skilled interviewers who not only are, but are also perceived by informants to be in-group members, and whose own linguistic repertoire features the same phenomena we are attempting to elicit" (1993:260), which can be difficult for a researcher not fluent in local dialects (NAGY; MEYERHOFF 2008:6; RAVINDRANATH 2015). Poplack's work also illustrates how important it is for data collection to be accompanied by long-term ethnolinguistic observations. Before hypotheses about language variation and change can be made, it is crucial to understand local patterns of language choice, attitudes toward local and surrounding languages and dialects, and language ideologies intrinsic to the particular context in order that the local sociolinguistic configuration can be understood and considered in the interpretation of variationist data.

Just as studies of monolingual dialects consider external factors in conjunction with language-specific internal constraints, so too should studies of coexisting language varieties. However, in contact situations the analyst should pay attention not only to traditional social factors, but also to the speaker's level of bilingualism, especially in communities where bilingualism is not stable and gradual language shift is occurring. In such a situation, common in immigrant communities, a wide range of bilingual proficiency may be found, including cases of attrition and incomplete acquisition. When studying such a community, bilingual proficiency must be assessed as part of the analysis (for this purpose, see POPLACK 1997; and the proposal of BIRDSON, GERTKEN; AMENGUAL 2012). Intensity of contact between the two languages may also be assessed by language patterns of different immigrant generations (see SILVA-CORVALÁN 1994), recency of arrival (OTHEGUY; ZENTELLA 2012), rate of code-switching (POPLACK; ZENTS; DION 2012; TORRES CACOULLOS; TRAVIS 2011), and status of the contact dialect as a majority or minority language in the community (POPLACK 1988), among many other factors. In addition, locally relevant categories may emerge from ethnographic observations, such as neighborhood of residence (POPLACK 1993), intensity of border crossing (CARVALHO 2004), domains of minority language use (RAVINDRANATH 2015; MOUGEON; NADASDI 1998), and life choices (GAL 1979). 
Cadernos de ESTUDOS LINGUísTICOS (58.3) - set./dez. 2016

Once the speech community has been established, data have been collected and transcribed, the linguistic variable has been chosen, and both internal and external factors have been operationalized, the next decision to be made concerns what constitutes a viable token in a passage of speech that includes items from the other language (that is, code-switching). Variationist methodology requires that quotations, fixed expressions, and false starts be excluded from the analysis; I submit that code-switches should be excluded as well. While the presence of code-switches should be noted, since this may be a factor underlying the variable output (as seen in TORRES CACOULLOS; TRAVIS 2015, ZABRODSKAJA 2013), segments in a different language should not be considered representative of the language under analysis, and therefore code-switched segments should be considered outside the envelope of variation.

Variationist analysis conducted in a contact situation presupposes the possibility that the other language may affect the output of a given variable that is susceptible to cross-linguistic influence, although there is no a priori assumption that such influence occurs. The possibility that language contact is inducing a change in the host dialect needs to be considered and tested in the analysis. When an innovative contact-induced variant is detected in a variable context where other non-contact-induced variant(s) coexist, this constitutes evidence for contact-induced change. A "diagnostic linguistic feature" (that is, a candidate for contact-induced change in a contact variety) is a feature that "is present in the presumed source variety and either 1) absent in the pre-contact or non-contact variety or 2) if present (e.g., through interlingual coincidence), is not conditioned in the same way as in the source, and 3) can also be shown to parallel in some non-trivial way the behavior of a counterpart feature in the source" (POPLACK; LEVEY 2010:397).

Thus, comparisons between dialects and languages are essential components of the variationist approach to language contact, since they allow for the detection of linguistic innovations (POPLACK; LEVEY 2010:401). Due to the rigor with which data collection and analysis are handled in the variationist approach, comparative sociolinguistics has established itself as a viable method for accurately detecting linguistic innovations by subjecting different data sets to the same multivariate analysis (TAGLIAMONTE 2013). When assessing the effect of language contact on a bilingual dialect, however, it is essential that the variety under examination be compared with an appropriate reference (POPLACK; LEVEY 2010).

What constitutes an appropriate reference is somewhat ill-defined. Most studies compare bilingual varieties to previous reports of the source language (CARVALHO 2010, among many others). Recent comparative sociolinguistic methods have allowed for the comparison of pairs of variable grammars. For example, in their study of immigrant groups of Spanish speakers in New York, Otheguy and Zentella (2012) compared variable patterns found among U.S.born Spanish speakers with those found among recent newcomers. Other scholars have compared patterns in the contact variety with ones found in surrounding monolingual varieties (AUGER; VILLENEUVE 2008, BESSETT 2015, SHIN; MONTE-ALCALÁ 2014; TORRES CACOULLOS; TRAVIS 
CARVALHO - The analysis of languages in contact: a case study though a variationist lens

2015, SHIN; VAN BUREN 2016, to name a few). Finally, the same speaker's variable grammars for both languages can also be compared, enabling crosslinguistic comparisons of grammars that coexist in the same community and even in the same speaker (CARVALHO; BESSETT 2015, KERN 2017, BLONDEAU; NAGY 2008).

Once the diagnostic variable has been chosen and the source dialect (the one modeling the contact feature) and the host variety (the one potentially replicating the feature) are established, both data sets are subjected to variationist analysis. These comparisons involve not only distributional frequencies, but also the processes that underlie the frequencies; namely, the factor groups that reach statistical significance and the ranking of factors within these groups (MEYERHOFF 2009a). The objective of such an analysis is to compare variable patterns in each language and determine if the patterns remain distinct, which constitutes evidence against language convergence. If patterns are similar, however, one needs to rule out the possibility that the similarities are due to interlingual coincidence or to linguistic universals before concluding that a contact-induced change has caused convergence (POPLACK; MEECHAN 1998); this is especially true when analyzing contact between cognate languages. For example, the careful study of contact between Portuguese and Spanish may distinguish typological coincidences from contact-induced convergences, following an exhaustive comparison of variable grammars, as illustrated below.

\section{PORTUGUESE AND SPANISH IN CONTACT IN NORTHERN URUGUAY}

The long-term coexistence of Portuguese and Spanish in bilingual communities in northern Uruguay presents an opportunity to study language variation and change with the goal of assessing the extent to which the languages have been modified due to contact. Portuguese and Brazilian settlers introduced Portuguese to the region during colonial times, when national borders were undefined. In fact, it was not until the last quarter of the nineteenth century that Spanish was imposed on northern Uruguay through nation-building measures intended to rid the region of Lusophone influences (ELIZAINCÍN 1992, BEHARES 1984, CARVALHO 2006b). Spanish was successfully imposed through obligatory public schooling and language policies, but Portuguese was maintained as a minority language, coexisting with the official Spanish in a more or less diglossic situation.

Currently, in urban centers in the region, the linguistic consequences of the long-term coexistence between Spanish and Portuguese can be seen mainly at the lexical level, following the general tendency for the lexicon to be most permeable in contact situations. In addition to code-switching - a frequent practice in bilingual communities around the world-lexical borrowings and calques are habitual, especially in Uruguayan Portuguese (henceforth UP), due to its status as the minority language (which is usually the recipient of lexical items from the majority 406 
Cadernos de ESTUDOS LINGUÍSTICOS (58.3) - set./dez. 2016

language). In fact, the abundance of Spanish lexical items in UP has led scholars to claim that it represents a case of a mixed code in which "true hybridization rather than simple bilingualism with codeswitching and borrowing" exists (LIPSKI 2006:8). The idea that UP represents a radical case of hybridization-a "new mixed language" dubbed Portuñol-presupposes that the hybrid has a set of linguistic norms that differ from those of the two original languages, as defined by Kerswill (2010:230). However, when qualitative or impressionistic generalizations are replaced by the rigor of variationist studies and comparative sociolinguistics, divergences emerge between the Spanish and Portuguese dialects spoken in these bilingual communities, as do continuities between the bilingual border dialects and their monolingual counterparts, countering the hypothesis that the languages have merged into a single code and pointing to the existence of a bilingual repertoire.

In fact, previous variationist studies of UP have demonstrated clear continuities with Brazilian Portuguese (henceforth BP) and divergences from Uruguayan Spanish. Vocalization of (lh), a common feature in rural BP, is replicated in UP with strikingly similar social and stylistic distribution (CARVALHO 2003). Nasalized vowels appear to have the same distributions in UP as BP: according to Castañeda (2011) they occur categorically in contexts of stressed syllables, following the pattern of BP but diverging from the Spanish oral vocalic inventory (217). In addition, in her analysis of (di, ti) palatalization in UP, Castañeda (2016) found striking similarities between UP and the patterns detected in a neighboring community in Rio Grande do Sul, Brazil, leading her to conclude, like Carvalho (2004) before her, that "Uruguayan Portuguese is marching alongside southern varieties of Brazilian Portuguese in response to regional changes" (15). Córdoba (2013) analyzed post-tonic mid vowel raising in UP, finding the raising pattern occurred on both sides of the Brazilian-Uruguayan border. Scholars have recently begun to explore morphosyntactic variables as well. Pacheco (2017) studied the variable use of 'a gente' as pronominalized first person plural in the Brazilian and Uruguayan sides of the cross-border town Aceguá, discovering that this innovation has entered UP as well.

The Spanish varieties spoken by Uruguayan bilinguals on the border have also been studied. Both Carvalho (2006a) and Waltermire (2008) studied syllable-final (s) aspiration and found that - contrary to claims in previous literature - (s) aspiration entered border Spanish in a variation pattern that very closely resembled patterns found among Spanish monolinguals in Montevideo. Finally, Carvalho (2010) examined the use of 'vos' and 'tú' as the second person address forms in border Spanish, finding that 'vos', the form preferred in Montevideo, was entering the border dialect, illustrating yet another continuity between bilingual and monolingual varieties despite the latter variety's contact with Portuguese. 
CARVALHO - The analysis of languages in contact: a case study though a variationist lens

\section{ASSESSING THE IMPACT OF LANGUAGE CONTACT THROUGH THE EXPRESSION OF THIRD-PERSON SUBJECT PRONOUNS AMONG PORTUGUESE-SPANISH BILINGUALS}

Subject pronoun expression is variable in many languages where verbal and contextual factors may allow the subject to be inferred without expression of the pronoun. Because this variable behaves differently in different languages, it has served as a diagnostic tool to assess the impact of language contact in several bilingual contexts. Nagy (2015) examined the impact of English on the output of subject pronouns in Cantonese, Italian, and Russian among bilinguals in Toronto; while Meyerhoff (2009a, 2009b) tested the influence of the substrate languages on subject pronoun realization in the English-based Creole Bislama. Barnes (2010) investigated the extent to which the behavior of this variable in Spanish changes among Mexicans who speak Venetian Italian, while Prada Pérez (2015) looked at the mutual influences of Spanish and Catalan in varieties spoken by bilinguals. The influence of English on linguistic constraints correlated with subject pronoun expression in U.S. varieties of Spanish has been the subject of several studies as well (see TORRES CACOULLOS; TRAVIS 2010, 2015; SHIN; MONTES ALCALÁ 2014; OTHEGUY; ZENTELLA 2012; among many others).

Carvalho and Bessett (2015) analyzed subject pronoun expression in both Spanish and Portuguese dialects in Uruguay. Given that, in general, Spanish tends to leave the subject pronoun unexpressed whereas Brazilian Portuguese is in the process of filling this syntactic slot with an explicit pronoun, the authors compared the output of this variable in both languages spoken by the same speakers in order to identify possible changes due to language contact. Analyzing all grammatical persons, the authors found that among abundant cross-linguistic commonalities due to typological coincidences, a couple of cross-linguistic differences emerged. First, in UP, the expression of the first-person plural pronoun 'a gente' ranks as the main condition for pronoun expression, whereas no equivalent is seen in Uruguayan border Spanish. In addition, the authors found that third-person singular subjects with inanimate referents were expressed differently when these bilinguals were speaking Spanish versus Portuguese, as described following.

Whereas Spanish continues to be regarded as a pro-drop language, there is broad consensus that BP has undergone a diachronic change toward overt pronoun expression over the last century (DUARTE 1993, 1995; among others). This innovation is believed to part of a parametric change toward a pro language, with possibly related changes in subject doubling, SVO order, and third-person expressed pronouns with inanimate referents (KATO; NEGRÃO 2000).

One indication that BP is well on its way to leaving its status as a prodrop language is the increasing tendency for pronoun expression with inanimate referents (DUARTE 1995:45). In Spanish, on the other hand, inanimate referents are categorically expected to trigger pronoun omission; hence, variationist studies of this variable do not include the inanimate context in quantitative analysis. This contrast between Spanish and Portuguese gives rise to a 'conflict site'; that is, a functional, structural, or quantitative difference that emerges in the comparison of the variable grammars of two languages (POPLACK; MEECHAN 1998:132). 
Cadernos de ESTUDOS LINGUÍSTICOS (58.3) - set./dez. 2016

For example, Torres Cacoullos and Travis (2015) present a good illustration of a conflict site. In their examination of subject pronoun expression in English and Spanish, they note that both languages tend to drop pronouns with coreferential coordinated verbs ('I arrive and Ø eat and Ø leave' in English and 'Yo llego, y $\varnothing$ como, y $\varnothing$ me voy', in Spanish). Thus, coreferential coordinated verbs present a coincidental site for both grammars, and cannot be used to diagnose language contact effects. Outside the context of and-coordination, however, unexpressed subjects in English occur mostly in the absolute initial position of an intonation unit (IU), as in 'gotta go', a context where Spanish pronoun expression is correlated to factors such as priming and subject continuity (p. 93). Having detected this 'conflict site', the authors examined pronoun expression in IU-initial position in Spanish in order to assess a potential English-contact-induced variation.

The usefulness of expression of subject pronouns with third-person singular referents as a diagnostic linguistic feature, or conflict site, finds support in the fact that Elizaincín (1995) considered pronoun expression with inanimate referents in Uruguayan Spanish a sign of Portuguese influence. In his qualitative analysis of rural Spanish varieties spoken in northern Uruguay, Elizaincín noted the presence of pronouns with inanimate third-person referents in monolingual Spanish. After mentioning a few examples and commenting on the novelty of the variant, he claimed that pronoun expression with inanimate referents was "very common in Spanish in current and past contact with the Portuguese spoken in the UruguayanBrazilian adjoining area, where both varieties have coexisted over the past two hundred years" (118). Having established that Spanish and Portuguese are expected to behave quantitatively differently in their distributions of third-person subject pronoun expression, and that Elizaincín has assumed that Portuguese has impacted northern Uruguayan Spanish in this regard, I now turn to the quantification of this variable. This example illustrates how the variationist method may contribute to the study of language contact by assessing the extent to which the varieties of Portuguese and Spanish spoken by bilinguals in northern Uruguay have been influenced by mutual contact.

\subsection{Method}

During fieldwork in Rivera, a border town on the Brazil-Uruguay border, I interviewed 85 bilinguals first in Spanish, the language used among strangers, then at a later date in Portuguese, the language usually preferred among acquaintances (CARVALHO 1998). For the present study, I randomly selected 18 interviews with the same participants in each language and coded them for subject pronoun expression. All speakers were bilingual and used both languages in daily interactions. All spoke fluently for an average of 50 minutes during their interviews and showed no signs of language attrition or incomplete acquisition through silences, hesitations, or frequent code-switches. All had been raised in Portuguesespeaking homes and acquired Spanish through schooling and socialization, excepted for one who reported to have been raised in a predominantly Spanishspeaking household, but who showed bilingual proficiency and linguistic behavior consistent with the other participants. 
Every occurrence of a conjugated verb that appeared either with or without a third-person singular pronoun was submitted to multivariate analysis in Rbrul $\left(\right.$ JOHNSON 2009) ${ }^{3}$. Analyses of Portuguese and Spanish included the same predictors based on previous scholarship about this variable summarized in Carvalho, Orozco, and Shin (2015:viv-xv). Speakers were included as a random effect. ${ }^{4}$

The variables are listed below:

- Tense, Mood, and Aspect (TMA): present, preterit, imperfect, future, conditional, and all periphrasis involving perfects;

- Presence or absence of a reflexive pronoun;

- Coreferentiality, or whether the token has the same referent as the previous verb, a different referent from the previous verb but the same referent as the previous object, or a different referent from both the previous subject and object (complete switch reference);

- Lexical content of the verb: cognitive versus others;

- Clause type: main, subordinate, or coordinate;

- Preservation, or whether the token is preceded by a verb with a coreferential expressed pronoun (E_), an unexpressed pronoun (Ø_), or a first token (a verb with a non-coreferential expressed/unexpressed pronoun);

- Degree of tangibility of the referent: concrete, abstract (non-tangible), nonconcrete but tangible, or locutionary;

- Definiteness: either definite or indefinite, depending on the type of determiner that preceded the referent;

- Specificity: either specific (referent is unique and not interchangeable) or non-specific (referent is not unique); and

- Animacy of the referent: human, non-human but animate, inanimate, or group of human elements (used in previous Portuguese studies only).

\subsection{Results}

Among the 883 tokens found in the Spanish corpus, 221, or 25\%, were verbs with an expressed pronoun, whereas among the 809 tokens found in Portuguese, 324 , or $40.2 \%$, were verbs with an expressed pronoun. Based solely on frequency, it is obvious that the structural similarities between Spanish and Portuguese do not necessarily result in linguistic convergence, as the rates are unambiguously different between the languages $\left(\chi^{2}=42.9(1), p<0.001\right)$.

\footnotetext{
${ }^{3}$ I thank Adriana Picoral Scheidegger for her assistance with codification and quantitative analysis. All errors are my responsibility.

${ }^{4}$ Social factors (age, social class, and gender) were discarded as nonsignificant by Rbrul when speaker as random effect was considered. Thus, this analysis was chosen over the alternative to avoid the fallacy of interpreting social factors in small groups when in fact differences are triggered by a few individuals.
} 


\section{Fig. 1: Pronoun expression with third-person singular referents in Spanish and Portuguese among the same bilinguals}

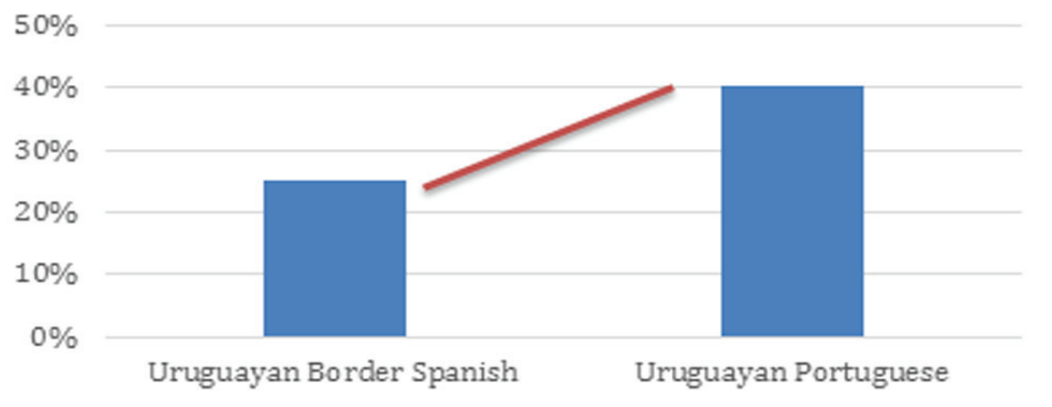

Although it would be ideal to compare these overall rates with counterparts in monolingual varieties, comparing these rates with rates reported in previous studies of distant dialects would be problematic for two reasons. First, rates differ within the same language, depending on the dialect, and I have been unable to locate similar studies of either the Spanish variety spoken in Montevideo or the Portuguese variety spoken in Rio Grande do Sul. Second, reported frequency differences may reflect different types of speech under analysis or different datacoding practices, rather than objective differences (TRAVIS 2007). In this case, however, both data sets under examination were extracted from the same type of sociolinguistic interview and subjected to the same coding practices by the same coder. Therefore, it is reasonable to infer that the overall frequency rates do in fact diverge, which suggests that this variable is treated differently for Spanish versus Portuguese in this speech community.

A cross-linguistic examination of factor group rankings (which factors are shown to be significant, and in what order), and constraint rankings (or how factors are ordered within selected factor groups) allows us to further compare and contrast the ways that this variable behaves in both languages.

Table 1: Multivariate analysis of third-person singular subject pronoun expression in UP and Uruguayan Border Spanish among bilinguals

\begin{tabular}{|c|c|c|c|c|c|}
\hline \multicolumn{3}{|c|}{ Uruguayan Portuguese } & \multicolumn{3}{|c|}{ Uruguayan Border Spanish } \\
\hline \multicolumn{3}{|c|}{$\begin{array}{c}\mathrm{N}=809 \\
40 \% \text { expressed }\end{array}$} & \multicolumn{3}{|c|}{$\begin{array}{c}\mathrm{N}=883 \\
25 \% \text { expressed }\end{array}$} \\
\hline Weight & $\mathrm{N}$ & $\%$ & Weight & $\mathrm{N}$ & $\%$ \\
\hline
\end{tabular}

Animacy

\begin{tabular}{|l|c|c|c|c|c|c|}
\hline Human & .88 & 534 & 56.9 & .88 & 611 & 36.0 \\
\hline Inanimate & .43 & 162 & 11.1 & .11 & 139 & 0.7 \\
\hline Group of humans & .14 & 113 & 2.7 & knockout & 133 & 0 \\
\hline
\end{tabular}


CARVALHO - The analysis of languages in contact: a case study though a variationist lens

\begin{tabular}{l}
\hline \hline Specificity \\
\begin{tabular}{|l|c|c|c|c|c|c|}
\hline Specific & .65 & 656 & 47.6 & .74 & 627 & 34.6 \\
\hline Non-specific & .34 & 153 & 8.5 & .26 & 123 & 3.3 \\
\hline
\end{tabular}
\end{tabular}

Coreferentiality

\begin{tabular}{|l|c|c|c|c|c|c|}
\hline Complete switch & .60 & 181 & 64.6 & .61 & 192 & 44.8 \\
\hline Switch subject, coref. obj. & .58 & 90 & 38.9 & .56 & 67 & 38.8 \\
\hline Coreferential subject & & & & & & \\
\hline
\end{tabular}

Pronoun Preservation

\begin{tabular}{|l|c|c|c|c|c|c|}
\hline E_ & .59 & 560 & 42.9 & .64 & 95 & 49.5 \\
\hline 1 st token & .57 & 113 & 53.1 & .51 & 445 & 31.0 \\
\hline$\varnothing_{-}$ & .33 & 136 & 18.4 & .34 & 210 & 17.1 \\
\hline
\end{tabular}

Reflexive pronoun

\begin{tabular}{|l|c|c|c|c|c|c|}
\hline Absent & .62 & 785 & 40.5 & {$[.73]$} & 217 & 29 \\
\hline Present & .37 & 24 & 29.2 & {$[.26]$} & 4 & 2.9 \\
\hline
\end{tabular}

While most factors selected by the analysis are identical, and their order of selection the same, a couple of differences are apparent. First, note that not all constraints are the same across the two languages, since the presence of a reflexive pronoun negatively affects the expression of a subject pronoun in Portuguese but is discarded as unimportant for the Spanish data. Animacy and specificity are equally important for both data sets, which is expected to be the result of interlingual coincidences, since they have been detected in previous studies of Spanish and Portuguese (CARVALHO; OROZCO; SHIN, 2015). Both factors are part of each language's core grammar and do not seem to be affected by any type of simplification due to bilingualism (countering SORACE, 2011). However, the next significant predictors of this variable in both languages, coreferentiality and pronoun preservation, show reversed order. While in Portuguese, coreferentiality is a slightly stronger predictor than pronoun preservation (.29 range vs. .26 range), in Spanish, pronoun preservation is slightly stronger than coreferentiality (.30 range vs. .29 range). The differential weighting signals a difference in the distributional behavior of this variable when the same bilingual speaks each language.

Meyerhoff (2009a:303) proposes a typology of transfers in assessing variable grammars. This typology differentiates between weak transfer (when both languages show the same factor groups as significant constraints), strong transfer (when the same factor groups are significant and the ordering of these factor groups is the same), and calquing (when not only are the same factor groups significant in the same order, but the ordering of these factor groups is also the same). However, applying Meyerhoff's typology to the analysis of contact between cognate languages presents a challenge since parallel variable structures are abundant due to equivalent diachronic developments. The distribution of variable pronoun expression is highly parallel in both Portuguese and Spanish, including the importance of expressing a 
pronoun after a switch in reference (a tendency seen in languages as different as Cantonese and Russian in NAGY et al. 2011), the repetition of a previously mentioned pronoun due to a tendency for linguistic forms to occur together in discourse, and the need to mark specific referents as opposed to nonspecific ones. Nevertheless, despite strong pre-contact similarities, slightly different constraint selection and constraint order across languages in the minds of these bilinguals do point to lack of convergence of variable grammars. Both similarities and discrepancies in constraint ranking are illustrated in the decision tree (BREIMAN et al. 1984), built based on the factors selected by Rbrul: animacy, specificity, coreferentiality and pronoun preservation, and in Figure 2.

Figure 2: Decision tree

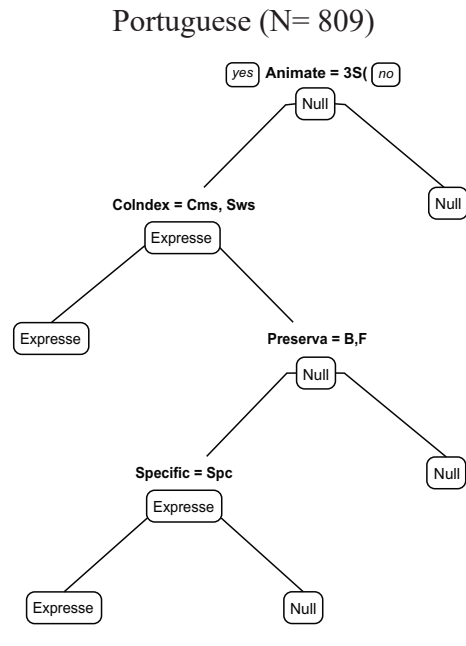

Accuracy: $75.15 \%$

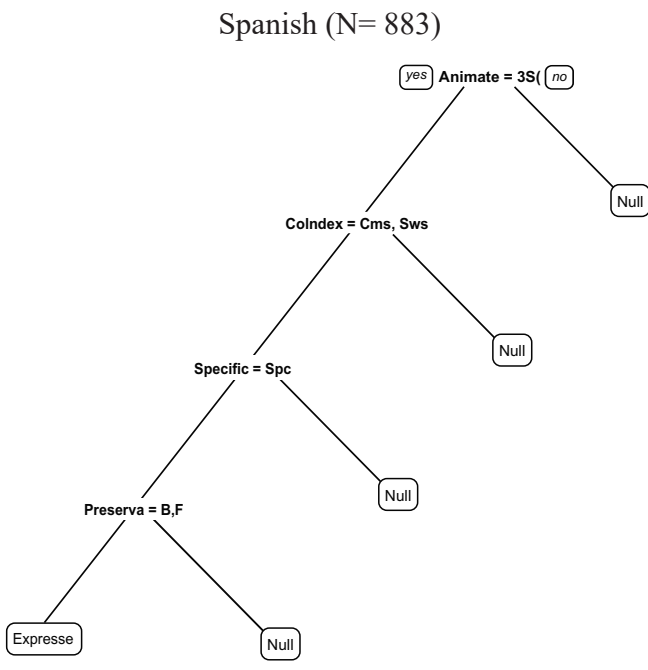

Accuracy: $78.6 \%$

An additional factor that can serve as a diagnostic linguistic feature is animacy, even though it is the most important factor group for both languages and the factors within this group are weighted in the same order. The magnitude of the effect, or the strength of the predictive power of the constraint (.43 for Portuguese against the nearly categorical .11 for Spanish), is the cross-linguistic difference that signals differential behavior across these languages, and thus, lack of linguistic convergence. Continuing to pursue this line of inquiry, I take a closer look at the quality and quantity of tokens in the 'animacy' group. Then, I examine in more detail the internal tendencies of both languages regarding the role of animacy in pronoun expression. Finally, I submit both data sets to a new analysis to test whether combining the corpora of both languages and creating the additional factor of language results in language becoming a significant factor in the logistic regression. This would provide further evidence for the independence of these variable grammars. 
As Table 1 shows, both languages demonstrated a tendency to express pronouns with animate referents and omit them with inanimate referents, but in Spanish there was only one occurrence of an expressed pronoun with an animate referent while in Portuguese there were 18. This important difference is even more relevant when we examine the single expressed pronoun token in Spanish, illustrated in (1):

(1) 'Ø tá guardada. Ella (una pistola) es protección de la casa' (3A)

"(It) is put away. She (the gun) is protection for the house"

This token refers to 'a gun' and its ability to protect the house, allowing for the interpretation that in fact the referent has some degree of animacy. Kittilä, Västi and Ylikoski (2011) claim that linguistic animacy is defined according to an entity's ability to act volitionally, which is why humans are regarded as the most animate entities. Following this logic, I submit that what could have instigated the pronoun expression in Spanish in Example (1) is the gun's human-like agency to protect the house (and the family inside it). Thus, in this semantic role, we can reinterpret 'la pistola' from an instrument to an agent due to its ability to protect the house, which renders its pronominalization less deviant from the Spanish monolingual norm. More importantly, the present analysis does not corroborate Elizaincín's (1995) claim that Uruguayan Spanish usually allows for expressed pronouns with inanimate referents as a result of contact with Portuguese.

Despite prolonged contact with Portuguese, the variety of Spanish spoken by bilinguals in this sample seems to maintain the tendency to avoid pronouns for inanimate referents. This is an interesting finding, especially given that there are varieties of Spanish where pronoun expression in this context does occur. Dominican Spanish, for example, shows a higher rate of pronoun expression than other dialects of Spanish in general, including use of pronouns with inanimate referents, ${ }^{5}$ as illustrated in (2):

(2) Pero ella (la laguna) antes estaba llena así (Bullock; Toribio 2009:57)

"But she (the lagoon) was full like this before"

The use of pronouns with inanimate referents and expletive pronouns, in addition to a fixed SVO order in Dominican Spanish, seems to some authors to point to a parametric change toward a pro language, similar to the change proposed for BP. However, literary evidence indicates that this variant may also be found in other varieties of Spanish. ${ }^{6}$ Consider Example (3) from the Peruvian writer Mario Vargas Llosa:

${ }^{5}$ Dominican Spanish presents the use of 'ello' as an overt expletive, which is considered a step toward a pro language (PÖLL 2015; BULLOCK; TORIBIO 2009). An example is, Ello parece que no hay azúcar (PÖLL 2015:329). This overt expletive is not present in BP.

${ }^{6}$ I would like to thank Ryan M. Bessett for providing me with these examples and for his inspiring and sound ideas about this subject. 
(3) La oposición ha desaparecido de la radio, de la televisión, de la prensa diaria en el Perú. Ella (la oposición) subsiste, mínima, hostigada, desde las columnas de todos los periódicos. (Butt; Benjamin 2013:133)

"The opposition has disappeared from the radio, from the television, from the daily newspaper in Peru. She (the opposition) subsists, minimal, harried, from the columns of all the news media."

Pronouns with inanimate referents were also found in Otheguy and Zentella's corpus of New York Spanish, as illustrated in (4):

(4) Se fue la luz pero ella vuelve a las 9 pm (OTHEGUY; ZENTELLA 2012:241)

"The power went out but she (the power) returns at 9 p.m."

In fact, this variant appears as early as the sixteenth century, in Miguel de Cervantes' Don Quijote:

(5) Acullá de improvise se le descubre un fuerte Castillo a vistoso alcazar cuyas murallas son de macizo oro; las almenas, de diamantes; las puertas de jacintos; finalmente, él (el Castillo) les dé tan admirable compostura [...] (Jensen 1973:119)

"Suddenly there is presented to his sight a strong castle or gorgeous palace with walls of solid gold, turrets of diamond, and gates of jacinth; in short, he (the castle) provides them with such admirable composition $[\ldots]$ "

Thus, it is indeed striking that despite the fact that a pronoun in this context would not be completely foreign to the Spanish language, and therefore could be easily adopted in a contact situation, the coexistence of Portuguese and Spanish in Rivera does not seem to have ignited this form in the Spanish variety spoken by these bilinguals in this corpus, except for one token illustrated in (1).

In contrast, in the Portuguese variety spoken by these bilinguals, the degree of animacy or semantic role of the subject did not seem to define pronoun use, since pronouns were used with referents such as fruit and body parts that have little or no ability to instigate events volitionally. The 18 tokens of expressed pronouns that referred to inanimate referents in the Portuguese interviews represent diverse lexical items, including ones related to food ('alface', "lettuce"; 'jaboticaba', a type of Brazilian grape; 'carne', “meat”), body parts ('cabelo', “hair”), machines ('carro', “car”), objects ('journal', “newspaper”), and events ('Copa América', "America Soccer Cup"). This comparison reveals clearly distinct cross-linguistic behavior: specifically, that UP, differently from Uruguayan Spanish, parallels BP in allowing third-person singular pronouns to be expressed with several types of inanimate referents, as example (6) illustrates: 
(6) Ele (o cabelo) é bem crespinho (12B)

"He (the hair) is very curly"

If relaxing the rule that pronouns are absent with inanimate referents is indeed a sign of movement toward a pro language, as has been claimed for BP (see Duarte 1995, among many others), then UP seems to be acquiring this change. The next question is, does UP present behavior that is different from BP due to its contact with Spanish? The search for an answer requires careful examination of the status of this variable in monolingual varieties of Portuguese. In a comprehensive review of studies of this variable in BP, Bravin dos Santos (2006) showed that animacy of the referent was the leading constraint on third-person singular pronoun expression in Rio de Janeiro in the 1970s, but had fallen to third place by the 1990s. As the author pointed out, however, inanimate referents continued to trigger fewer pronouns than animate ones, which represents a residual trace of a true pro-drop language. Perhaps various degrees of animacy constraints represent different stages in the development toward becoming a pro language. Costa (2000) studied this variable in Gaucho Portuguese, a variety of BP spoken in the border state of Rio Grande do Sul and, as such, a much more relevant comparison dialect for UP. In her corpus, third-person singular pronouns were commonly used with animate referents while inanimate referents triggered higher rates of either pronoun omission or full noun phrases. Costa's quantitative analysis is different from the present one, so it does not allow for direct comparisons that would indicate where Gaucho Portuguese is situated on the continuum of this change in progress relative to, for example, the well-studied varieties of Rio de Janeiro. Since different dialects of BP may be located at different points along the trajectory toward pronoun expression with inanimate referents, a study similar to the current one, but on the Brazilian side of the Uruguayan border, would be useful to provide a sound comparison between monolingual and bilingual varieties of Portuguese in the area. ${ }^{7}$ In the absence of such studies, there is no evidence to conclude whether or not the rate of pronoun expression with inanimate referents in UP is lower than in surrounding dialects of BP due to contact with Spanish.

In any case, qualitative analysis of token types with expressed pronouns in Spanish and Portuguese, combined with examination of internal tendencies in both languages, does not establish conclusive evidence that pronoun expression is undergoing linguistic convergence. The results in the 'animacy' factor group revealed a cross-linguistic conflict that was manifested not in differences in constraint hierarchies but in magnitude of effect. Thus, we were unable to prove contact-induced change despite typological similarity in a prolonged contact situation, and found no evidence that would back up Elizaincín's impression that third-person subject pronoun expression with inanimate referents is widespread in northern Uruguay due to contact with Portuguese.

\footnotetext{
${ }^{7}$ The author has made several attempts to access the Varsul database but was informed that it is not yet an open corpus because it has not been anonymized.
} 
Cadernos de ESTUDOS LINGUÍSTICOS (58.3) - set./dez. 2016

Finally, in order to further test the presumed lack of convergence, I ran an Rbrul analysis with both data sets together, including 'language' (Portuguese or Spanish), as an additional factor group. The rationale for this test was that this factor would be statistically significant if the languages remained distinct in the way this variable was distributed but would be insignificant if the two systems had indeed converged into a single one. The addition of the language factor did not significantly affect the results presented in Table 1, except that language was indeed a significant predictor for the output of the variable, as shown in Table 2.

Table 2: Language as a factor in the output of third-person singular pronouns among bilinguals in Rivera, Uruguay

\begin{tabular}{|c|c|c|c|}
\hline Language & Weight & N & \% \\
\hline Portuguese & 0.618 & 809 & 40.2 \\
\hline Spanish & 0.382 & 883 & 25.0 \\
\hline
\end{tabular}

Table 2 illustrates that both languages are significant predictors of pronoun rates, but in opposite directions. Spanish shows a negative (that is, below 0.5) probability weight that third-person singular pronouns will be expressed (0.382), while Portuguese shows a positive weight (0.618). Once again, there is no statistical support for an interaction between the languages or for leveling of language-specific linguistic behavior in third-person pronoun rates due to language contact. This provides further evidence that even though the languages present parallel variability, as shown in Table 1, they have not merged into a single variable system, as evidenced by the greater tendency to express pronouns in UP than in border Uruguayan Spanish overall, particularly in contexts where the referent is inanimate.

\section{CONCLUSION}

This study has explained and illustrated the application of variationist sociolinguistics to the assessment of contact-induced language changes. The use of a method from comparative sociolinguistics has allowed for a detailed examination of third-person singular pronoun expression in Spanish and Portuguese in northern Uruguay, where the two languages are in contact. Analogous multivariate analyses of both languages spoken by bilinguals showed that despite ample parallel variability due to parallel linguistic developments, the languages have not converged into a single variable third-person singular pronoun system. The difference is more easily seen in the expression of pronouns with inanimate referents, since Spanish seems to be immune to the growing Portuguese tendency toward pronoun expression in this context. In light of some qualitative evidence that pronoun expression may occur in this context in certain Spanish varieties, it is truly remarkable that the only token found in the present corpus can be interpreted as having a human-like semantic role of 'agent'. 
The possibility that Spanish may have influenced Uruguayan Portuguese remains unproven, since it would be important to examine the Gaucho varieties of Portuguese to assess the extent to which the general tendency toward pronoun expression in Rio de Janeiro, including in contexts where the referent is inanimate (Duarte 1995), is also present in Rio Grande do Sul, the BP variety with which border residents are in daily contact. Previous studies of Portuguese varieties on both sides of the Brazil-Uruguay border have demonstrated that some variables that are considered nearly categorical in central Brazil, such as unstressed /o/ raising (CÓRDOBA 2013) and pronominal 'a gente' (PACHECO 2017), show variable behavior in the border region, probably indicating that rural Gaucho Portuguese maintains more conservative behavior. If this is true for pronoun expression as well, it would explain the low (11\%) pronoun rates with inanimate referents, considered to be one of last environments to be filled during the change toward pronoun expression, since this variable, particularly in this context, seems to be implicated in ongoing change. If similar variationist studies show that this linguistic change is in fact more advanced in rural Gaucho Portuguese, the hypothesis that contact with Spanish may be hindering change in UP would need to be revisited.

It is worth pointing out the utility of this framework for studying several contact dialects in BP that remain unanalyzed. Given that localities where Portuguese is in contact with other languages are abundant around the world, and that variationist sociolinguistics is an extremely productive subfield of Brazilian linguistics, it is indeed surprising that most of the scholarship revolves around monolingual varieties of Portuguese. In addition to existing as an official language in several multilingual countries, Portuguese is also spoken by dwellers in border communities, by migrants in the diaspora, by residents in former colonies, and by individuals learning Portuguese as a foreign language. All these contexts give rise to situations of language contact that are of scholarly interest to the field of variationist sociolinguistics.

In Brazil, the hegemonic imposition of Portuguese on speakers of indigenous languages has been ongoing since the conquest and has continued after the nation's independence from Portugal through language policies imposed by the Brazilian government. The monolingual Portuguese policy successfully promoted linguistic and cultural assimilation, as evidenced in the fact that by the first half of the twentieth century, nearly 70 indigenous Brazilian languages had become extinct (MÜLLER DE OLIVEIRA 2009). Of the estimated 1,000 languages spoken in Brazil at the time of the Portuguese arrival, only 170 are still spoken currently, mostly by bilinguals whose Portuguese presents unique phonological and morphosyntactic features that remain unexamined (see, for example, EMMERICH; PAIVA 2009, CHRISTINO; LIMA 2012).

Language policies reinforcing monolingualism in Brazil have also affected language shift among immigrants. Perhaps one of the most striking examples of this is from Getulio Vargas' dictatorship (1937-1945) when the use of German and Italian was forcefully repressed and punished in communities in southern Brazil (see, among others, MÜLLER DE OLIVEIRA 2009; VANDRESEN 2009). Nevertheless, some immigrant groups have maintained Japanese, Italian, or Pommersch as home languages. More recent Chinese, Korean, and Spanish immigrants have contributed to multilingualism in Brazil, giving rise to contact varieties of Portuguese prime for linguistic analysis, which has only just begun (see BI 2013; BREMENKAMP 2014). 
Portuguese-based creoles in Africa and Asia are also appropriate for variationist analysis that would shed light on contact-induced linguistic changes contributing to the formation of new varieties (see the summary of studies about these varieties in CARVALHO; LUCCHESI 2016). While multi-regression analyses have revealed intricate relationships between Brazilian and European varieties of Portuguese, thus breaking new ground in the debate about the origin of Brazilian Portuguese (NARO; SCHERRE 2007), a plethora of studies on contact varieties of Portuguese lie ahead for linguists trained in variationist sociolinguistics. I hope that some will find inspiration here.

\section{REFERENCES}

AARON, Jessi Elana (2014) Lone English-origin nouns in Spanish: The precedence of community norms (Special issue, Gauging convergence on the ground: code-switching in the community, edited by Catherine E. Travis and Rena Torres Cacoullos). International Journal of Bilingualism.

AUGER, Julie; VILLENEUVE, Anne-José (2008) Ne deletion in Picard and in regional French. In: MEYERHOFF, Miriam; NAGY, N. (eds.) Social Lives in Language - Sociolinguistics and multilingual speech communities: Celebrating the work of Gillian Sankoff. Amsterdam/ Philadelphia: John Benjamins, p. 223-247.

BARNES, Hilary (2010) Subject pronoun expression in bilinguals of two null subject languages. In: ARREGI, Karlos; FAGYAL, Zsuzsanna; MONTRUL, Silvina; TREMBLAY, Annie (eds.) Romance Linguistics 2008: Interactions in Romance. Selected papers from the 38th Linguistic Symposium on Romance Languages (LSRL), Urbana-Champaign, April 2008 (Vol. 313, p. 9). John Benjamins Publishing.

BEHARES, Luiz Ernesto (1984) Diglosia en la sociedad escolar de la frontera uruguaya con Brasil: Matriz social del bilingüismo. Cuadernos de estudios lingüisticos 6, 229-234.

BESSETT, Ryan M. (2015) The extension of estar across the Mexico-US border: Evidence against contact-induced acceleration. Sociolinguistics Studies 9 (4), 421-443.

BESSETT, Ryan M. (2017) The Integration of Lone English Items into Bilingual Sonoran Spanish. Ph.D. Dissertation. University of Arizona.

BI, Meng Win (2013) Imigração chinesa em São Paulo e seu português falado. Interlíngua e marcadores discursivos. Master's Thesis. University of Sao Paulo.

BIRDSONG, D.; GERTKEN, L.M.; AMENGUAL, M. (2012) Bilingual language profile: An easy-touse instrument to assess bilingualism. COERLL, University of Texas at Austin.

BLAS ARROYO, José Luis (2015) The scope of language contact as a constraint factor in language change: the periphrasis haber de + infinitive in a corpus of language immediacy in modern Spanish. International Journal of Bilingualism. 19, 499-524.

BLONDEAU, Hélène; NAGY, Naomi. (2008) Subordinate clause marking in Montreal Anglophone French and English. In: MEYERHOFF, Miriam; NAGY, N. (eds.) Social Lives in Language Sociolinguistics and multilingual speech communities: Celebrating the work of Gillian Sankoff. Amsterdam/Philadelphia: John Benjamins, p. 273-313. 
CARVALHO - The analysis of languages in contact: a case study though a variationist lens

BRAVIN DOS SANTOS, Angela Marina. (2006) $O$ sujeito anafórico de $3^{a}$ pessoa na fala culta carioca: um estudo em tempo real. Ph.D. Dissertation. Federal University of Rio de Janeiro.

BREIMAN, Leo; FRIEDMAN, Jerome H.; OLSHEN, R. A.; STONE, Charles J. Classification and regression trees. California: Wadsworth \& Brooks. 1984.

BREMENKAMP, Elizana S. (2014) Análise sociolingüistica da manutenção da língua pomerana em Santa Maria de Jetibá, Espirito Santo. Master's Thesis. Federal University of Espírito Santo.

BULLOCK, Barbara E.; TORIBIO, Almeida J. (2009) Reconsidering Dominican Spanish: data from the rural Cibao. Revista Internacional de Lingüistica Iberoamericana 7(2), 49-73.

BUTT, John; BENJAMIN, Carmen (2013) A new reference grammar of modern Spanish. New York: Routledge.

CARVAlHO, Ana Maria (1998) The Social Distribution of Uruguayan Portuguese in a Bilingual Border Town. PhD Dissertation. University of California, Berkeley.

CARVALHO, Ana Maria (2003) The sociolinguistic distribution of (lh) in Uruguayan Portuguese: a case of dialect diffusion. In: MONTRUL, S.; ORDÓÑEZ, F. Linguistic theory and language development in Hispanic Languages. Summerville, MA: Cascadilla Press, p. 30-44.

CARVALHO, Ana Maria (2004) I speak like the guys on TV: palatalization and the urbanization of Uruguayan Portuguese. Language Variation and Change 16(2), 127-151.

CARVALHO, Ana Maria Spanish (2006a) (s) aspiration as a prestige marker on the UruguayanBrazilian border. Spanish in Context 3(1), 85-114.

CARVALHO, Ana Maria (2006b) Políticas lingüísticas de séculos passados nos dias de hoje: O Dilema sobre a educação bilíngüe no Uruguai. Language Problems and Language Planning. 31(1), 140-171.

CARVALHO, Ana Maria (2010) ¿Eres de la frontera o sos de la capital? Variation and alternation of second-person verbal forms in Uruguayan border Spanish. Southwest Journal of Linguistics 29(1), 1-24.

CARVALHO, Ana Maria; BESSETT, Ryan M. (2015) Subject pronoun expression in Spanish in contact with Portuguese. In: CARVALHO, A.M.; OROZCO, R.; SHIN, N. (eds.) Subject Pronoun Expression in Spanish: A Cross-Dialectal Perspective. Georgetown University Press, p. 143-166.

CARVALHO, Ana Maria; LUCCHESI, Dante. (2016) Portuguese in Contact. In: WETZELS, W. Leo; MENUZZI, Sergio; COSTA, João (eds.) Handbook of Portuguese Linguistics. WileyBlackwell.

CARVALHO, Ana Maria; OROZCO, Rafael; SHIN, Naomi L. (2015) Subject pronoun expression in Spanish: A cross-dialectal perspective. Georgetown University Press.

CASTAÑEDA, Rosa Maria (2011) Linguistic Variation in a Border Town: Palatalization of Dental Stops and Vowel Nasalization in Rivera. Ph.D. Dissertation. University of Florida. ProQuest LLC.

CASTAÑEDA, Rosa Maria (2016) The Sociolinguistic Evolution of a Sound Change. Journal of Portuguese Linguistics 15(3).

CHRISTINO, Beatriz; LIMA, Moana de. (2012) Concordância verbal e nominal na escrita em Português-Kaingang//Verbal and nominal agreement in Portuguese-Kaingang texts. PAPIARevista Brasileira de Estudos Crioulos e Similares 22(2), 415-428. 
$\overline{\text { CÓRDOBA, Alexander S. (2013) A neutralização das vogais postônicas finais no português uruguaio }}$ falado na cidade de Tranqueras-Uruguai. Master's thesis. Universidade Católica de Pelotas, Pelotas.

COSTA, Iara B. (2000) Cadeias referenciais no português falado. Organon 14 (28-29), 33-54.

DUARTE, Maria Eugênia Lamoglia. (1993) Do pronome nulo ao pronome pleno: a trajetória do sujeito no português do Brasil. Português brasileiro: uma viagem diacrônica. Campinas: Editora da Unicamp, p. 107-128.

DUARTE, Maria Eugênia Lamoglia. (1995) A perda do principio "evite pronome" no português brasileiro. In: Ian Roberts and Mary Kato. Português Brasileiro: Uma viagem diacrônica. Campinas: Editora da Unicamp, p.107-128.

ELIZAINCÍN, Adolfo (1992) Dialectos en contacto. Español y Portugués en España y América. Montevideo: Arca.

ELIZAINCÍN, Adolfo (1995) Personal pronouns for inanimate entities in Uruguayan Spanish in contact with Portuguese. In: SILVA-CORVALÁN, Carmen (ed.) Spanish in Four Continents: Studies in Language Contact and Bilingualism. Washington DC: Georgetown University Press, p.117-131.

EMMERICH, Charlotte; PAIVA, Maria da Conceição de. (2009) Português xinguano: origem e trajetória. In: CARVALHO, Ana Maria (eds.) Português em contato. Madrid: Iberoamericana, p. 153-164.

GAL, Susan. (1979) Language Shift: Social Determinants of Linguistic Change in Bilingual Austria. Academic Press.

GORDON, Matthew. (2006) Interview with William Labov. Journal of English linguistics 34(4), $332-351$.

JENSEN, John B. (1973) The Feature [ \pm human] as a Constraint on the Occurrence of Third-person Subject Pronouns in Spanish. Hispania 56(1), 116-122.

JOHNSON, Daniel Ezra. (2009) Getting off the GoldVarb standard: Introducing Rbrul for mixed effects variable rule analysis. Language and Linguistics Compass 3(1), 359-383.

KATO, Mary A.; NEGRÃO, Esmeralda V. (2000) Brazilian Portuguese and the null subject parameter (Vol. 4). Frankfurt am Main: Iberoamericana.

KERN, Joseph J. (2017) Discourse-pragmatic features in English and Spanish among bilinguals. Ph.D. Dissertation. University of Arizona.

KERSWILL, Paul. (2010) Contact and new varieties. In: HICKEY, Raymond (ed.). The Handbook of Language in Contact. Oxford: Wiley-Blackwell, p. 230-251.

KITTILÄ, Seppo; VÄSTI, Katja; YLIKOSKI, Jussi (2011) Case, Animacy and Semantic Roles. Typological Studies in Language 99. Amsterdam/Philadelphia: John Benjamins.

LABOV, William (1966) Hypercorrection by the lower middle class as a factor in linguistic change. Sociolinguistics: Proceedings of the UCLA Sociolinguistics Conference, 1964. The Hague: Mouton, p. 84-113.

LABOV, William. (1972) Sociolinguistic patterns. Philadelphia: University of Pennsylvania Press. 
CARVALHO - The analysis of languages in contact: a case study though a variationist lens

LIPSKI, John (2006) Too close for comfort? The genesis of "portuñol/portunhol". In: Selected Proceedings of the 8th Hispanic Linguistics Symposium, 1-22.

MEYERHOFF, Miriam. (2009a) Animacy in Bismala? In: STANFORD, James; PRESTON, Dennis R. (eds.) Variation in Indigenous Minority Languages. Amsterdam/Philadelphia: John Benjamins, p. 369-396.

MEYERHOFF, Miriam. (2009b) Replication, transfer, and calquing: Using variation as a tool in the study of language contact. Language Variation and Change 21(3), 297-317.

MOUGEON, Raymond; BENIAK, Édouard (1991) Linguistic Consequences of Language Contact and Restriction The Case of French in Ontario, Canada. Oxford: Oxford University Press.

MOUGEON, Raymond; NADASDI, Terry (1998) Sociolinguistic discontinuity in minority language communities. Language, 40-55.

MÜLLER DE OLIVEIRA, Gilvan. (2009) Brasileiro fala português: monolingüismo e preconceito lingüístico. Rev Linguagem 11(1), 1-9.

NAGY, Naomi. (2015) A sociolinguistic view of null subjects and VOT in Toronto heritage languages. Lingua 164, 309-327.

NAGY, Naomi; AGHDASI, Nina; DENIS, Derek; MOTUT, Alexandra. (2011) Null subjects in heritage languages: Contact effects in a cross-linguistic context. University of Pennsylvania Working Papers in Linguistics, 17(2), 16.

NAGY, Naomi; MEYERHOFF, Miriam Introduction. (2008) In: MEYERHOFF, Miriam; NAGY, N. (eds.) Social Lives in Language - Sociolinguistics and multilingual speech communities: Celebrating the work of Gillian Sankoff. Amsterdam/Philadelphia: John Benjamins, p. 1-16.

NARO, Anthony; SCHERRE, Maria Marta Pereira (2007) Origem do português brasileiro. São Paulo: Parábola.

OTHEGUY, Ricardo; ZENTELLA, Ana Celia. (2012) Spanish in New York: Language contact, dialectal leveling, and structural continuity (Vol. 203). OUP USA.

PACHECO, Cintia S. (2017) Identidade sociolinguística na fronteira de Aceguá (Brasil-Uruguai). Revista de Estudos da Linguagem. 25 (1), 276-304.

PÖLL, Bernhard (2015) Caribbean Spanish = Brazilian Portuguese? Some comparative thoughts on the loss of pro-drop. Studies in Lusophone and Hispanic Linguistics 8(2), 317-356.

POPLACK, Shana (1988) Language status and language accommodation along a linguistic border. In: LOWENBERG, P. (ed.) GURT 87: Language spread and language policy: issues, implications, and case studies. Washington, D.C.: Georgetown University Press, p. 90-118.

POPLACK, Shana (1993) Variation theory and language contact. In: PRESTON, Dennis. (ed.) American dialect research. Amsterdam: Benjamins, p. 251-286.

POPLACK, Shana (1997) The sociolinguistic dynamics of apparent convergence. Amsterdam Studies in the Theory and History of Linguistic Science Series 4, p. 285-310.

POPLACK, Shana; LEVEY, S. (2010) Contact-induced grammatical change: A cautionary tale. Language and space: An international handbook of linguistic variation, 1, p. 391-419.

POPLACK, Shana; MEECHAN, Marjory (1998) How Languages Fit Together in Codemixing. International Journal of Bilingualism, 2(2), 127-138. 
POPLACK, Shana; SANKOFF, David; MILLER, Christopher. (1988) The social correlates and linguistic processes of lexical borrowing and assimilation. Linguistics 26(1), 47-104.

POPLACK, Shana, ZENTZ, Lauren; DION, Nathalie (2012) Phrase-final prepositions in Quebec French: An empirical study of contact, code-switching and resistance to convergence. Bilingualism: Language and Cognition 15(02), 203-225.

PRADA PÉREZ, Ana (2015) First person singular subject pronoun expression in Spanish in contact with Catalan. In: CARVALHO, A.M.; OROZCO, R.; SHIN, N. (eds.) Subject Pronoun Expression in Spanish: A Cross-Dialectal Perspective. Georgetown University Press, p. 121-142.

RAVINDRANATH, Maya. (2015) Sociolinguistic Variation and Language Contact. Language and Linguistics Compass, 9(6), 243-255.

RICKFORD, John (1980) Analyzing Variation in Creole Languages. In: VALDMAN, A.; HIGHFIELD, A. (eds) Theoretical Orientations in Creole Studies. New York: Academic Press, p. 165-184.

SANKOFF, Gillian (1980) The Social Life of Languages. Philadelphia: University of Pennsylvania Press. 1980

SHIN, Naomi L.; MONTES-ALCALÁ, Cecilia. (2014) El uso contextual del pronombre sujeto como factor predictivo de la influencia del inglés en el español de Nueva York [English influence on Spanish in New York: Evidence from subject pronouns in context]. Sociolinguistic Studies $8(1)$, p. 85 .

SHIN, Naomi L.; VAN BUREN, Jackelyn (2016) Maintenance of Spanish subject pronoun expression patterns among bilingual children of farmworkers in Washington/Montana. Spanish in Context 13(2), 173-194.

SILVA-CORVALÁN, Carmen (1994) Language Contact and Change: Spanish in Los Angeles. Oxford: Oxford University Press.

SORACE, Antonella. (2011) Pinning down the concept of "interface" in bilingualism. Linguistic approaches to bilingualism 1(1), 1-33.

TAGLIAMONTE, Sali A. (2013) Comparative sociolinguistics. In: CHAMBERS, J.K.; SCHILLING, Natalie. The Handbookf of Language Variation and Change. Oxford: John Wiley \& Sons, p. 128-156.

TORRES CACOULLOS, Rena; AARON, Jessi Elana. (2003) Bare English-origin nouns in Spanish: Rates, constraints, and discourse functions. Language Variation and Change 15(3), 289-328.

TORRES CACOULLOS, Rena; TRAVIS, Catherine E. (2010) Variable yo expression in New Mexico: English influence? In: RIVERA-MILLS, Susana; VILLA, Daniel (eds.). Spanish of the Southwest: A language in transition. Frankfurt: Iberoamericana/Vervuert, p. 185-206.

TORRES CACOULLOS, Rena; TRAVIS, Catherine E. (2015) Foundations for the Study of Subject Pronoun Expression in Spanish in Contact with English: Assessing Interlinguistic (Dis) similarity via Intralinguistic Variability. In: CARVALHO, A.M.; OROZCO, R.; SHIN, N. (eds.) Subject Pronoun Expression in Spanish: A Cross-Dialectal Perspective. Georgetown University Press, p.81-100.

TRAVIS, Catherine E. (2007) Genre effects on subject expression in Spanish: Priming in narrative and conversation. Language Variation and Change 19(2), 101-135. 
CARVALHO - The analysis of languages in contact: a case study though a variationist lens

VANDRESEN, Paulino. (2009) Estudo comparativo do bilinguismo em duas áreas de colonização alemã. In: CARVALHO, Ana M. (ed.) Português em contato. Madrid: Iberoamericana, p. 199-214.

WALTERMIRE, Mark. (2008) Social stratification of language-specific variants of intervocalic /d/ along the Uruguayan-Brazilian border. Sociolinguistic Studies 2(1), 31-60.

WEINREICH, Uriel. (1953) Languages in Contact. New York: Linguistic Circle of New York. Indian Journal of American Studies.

WEINREICH, Uriel; LABOV, William; HERZOG, Marvin I. (1968) Empirical foundations for a theory of language change. Austin: University of Texas Press, p. 95-195.

ZABRODSKAJA, Anastassia. (2013) Morphosyntactic contact-induced language change among young speakers of Estonian Russian. In: LÉGLISE, Isabelle; CHAMOREAU, Claudine (eds.) The interplay of variation and change in contact settings. Amsterdam: John Benjamins, p. 77-106. 